\title{
US awaits FDA appointment
}

Although President Bush has been quick to appoint a new Secretary for the department of Health and Human ServicesTommy Thompson-the administration has still to appoint a successor to the United States Food and Drug Administration (FDA) commissioner, Jane Henney.

Political appointees are required to leave with their president, but some Democrats claim Henney was forced out. She was the first

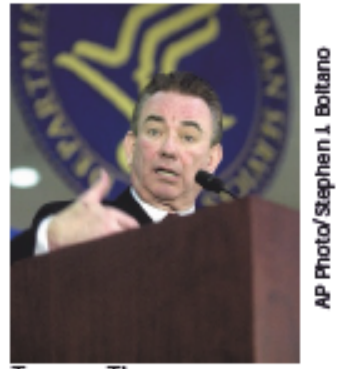

Tommy Thompson
133; 1999). US Surgeon General David Satcher, a Clinton holdover, was named acting commissioner.

A new commissioner will likely be chosen for his/her ability to follow the Republican Party line, which is anti-big government and ant-abortion, according to Washington insiders, who add that that person will be unlikely to take a strong stance against issues such as tobacco or genetically woman commissioner and was a stronger proponent of increasing the science base at the FDA (Nature Med. 5 ,

modified foods.

Carl Feldbaum, Biotechnology Industry
Organization president for the past 8 years and a Bush transition adviser, says that he has warned against choosing an ideologue. But it looks like the new commissioner's first act will be to overturn the approval of the abortion bill, RU-486-a drug that, during his confirmation hearings, Thompson said he would like to see withdrawn.

Feldbaum believes that the administration will try to avoid this, if only because a lengthy political battle at the start of the administration will distract the new commissioner from more important business, such as negotiations over the reauthorization of the Prescription Drug User Fee Act, which speeds drug reviews and is due to expire in October 2002.

Alicia Ault, Maryland

\section{HHS advises IRBs on conflict issues}

The US Department of Health and Human Services (HHS) has released a draft document offering guidance to Internal Review Boards (IRBs) connected to medical research institutions on how to handle financial conflicts of interest and their potential impact on patient protection.

IRBs are charged with ensuring that human research meets strict ethical and safety standards. HHS reports that only $25 \%$ of IRBs evaluate conflicts of interest when reviewing research proposals. Hence HHS advises hospitals and medical schools to collect and review information on any financial relationships that could "significantly affect the design, conduct, or reporting" of federally sponsored medical research. Those financial relationships can range from stock ownership to 'finder's fees' paid for each enrolled patient.

In addition, the document also suggests that the institutions find a way to evaluate their own conflicts of interest. including equity ownership in companies sponsoring clinical trials. Finally, HHS suggests that information about a researcher's possible conflicts be included in patient consent forms.

The report advises that if a researcher has a conflict, "he or she should not be directly engaged in aspects of a trial that could be influenced inappropriately by that conflict." But David Korn, a policy analyst with the American Association of Medical Colleges, says that institutions need to be allowed to make their own judgment on such matters. "(T)here are occasions in some early Phase I clinical research in which the in- ventor of a new technology is unarguably the best qualified individual to conduct the research and ensure patient safety, irrespective of whether he/she has a real or potential financial conflict in the outcome," he says. "Accordingly, we strongly believe that flexibility is important in dealing with such circumstances."

But Sidney Wolfe, director of the consumer organization Public Citizen Health Research Group, does not think that the guidelines go far enough. Patient safety would best be served if certain financial relationships are designated as "out of bounds," he says, giving the example that a researcher with $\$ 100,000$ worth of stock in a company should not be allowed to run trials of that company's products. "There is nothing like that at all in this document," he criticizes. "It is extremely weak. The people in the government seem to...believe that conflicts of interest are here to stay and that the remedy is to collect information and disclose."

\section{In other news...}

In what is believed to be the first lawsuit against members of an IRB, patients who participated in a melanoma vaccine trial at the University of Oklahoma sponsored by the biotechnology company, Immunex, have sued the School and its IRB for fraud and failure to notify them of study risks. The Food and Drug Administration halted the trial last year, citing problems with patient safety and drug manufacturing (Nature Med. 6, 946; 2000).

Tinker Ready, Boston

\section{FDA to regulate tissue banks}

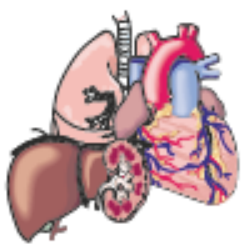

$\begin{array}{ll}\text { The US } & \text { Food } \\ \text { and } & \text { Drug }\end{array}$

Administration (FDA) is tightening its grip on the largely unregulated industry of tissue banking. It has introduced regulations requiring that all tissue banks register with the FDA, and has proposed new rules for "good tissue practice" procedures to ensure that the industry standardizes manufacturing methods and that their products are not damaged during processing or contaminated by infectious agents.

Tissue banks are distinct from organ procurement organizations, whose job it is to obtain bone marrow and solid organs such as kidneys, hearts and lungs for transplant. Tissue banks obtain, store, process and distribute cell and tissue-based products for clinical and cosmetic purposes. Their most common products are skin for treating severe burns, heart valves and corneas as well as tendons and ligaments for reconstructive surgery.

The FDA requires most tissue banks to test their products for HIV and hepatitis viruses $B$ and $C$, and those companies already subject to pathogen-testing requirements must register within three months. Others, primarily oocyte and sperm banks and companies that derive stem cells from peripheral and umbilical cord blood, must register within two years. Registration is not required of suppliers of cells and tissues for non-clinical 